\title{
Active Student Learning through Gamification in a Learning Management System
}

\author{
Satrio Raffani Raharjo, Putu Wuri Handayani and Panca Oktavia Hadi Putra \\ Universitas Indonesia, Indonesia \\ satrio.raffani@ui.ac.id \\ putu.wuri@cs.ui.ac.id \\ hadiputra@cs.ui.ac.id
}

\begin{abstract}
E-learning through a learning management system (LMS) is expected to be a solution to the needs of distance learning, especially during a pandemic situation. However, learning through an LMS can lead to a lack of focus, reduced classroom efficiency, and a feeling of boredom for the user. One solution to this problem is to use gamification (e.g., rankings or points, badges, and leaderboards) to enhance active learning. This study uses a mixed-methods approach and data from weekly reviews and forum discussions, questionnaires, and data students' interviews to assess the implementation of gamification elements in an LMS. The data from the questionnaires were analyzed using descriptive statistics, and the data from student interviews were analyzed using general inductive analysis. The results show that gamification in an LMS had a positive influence on active learning. The students have also provided positive feedback on the rated weekly review activity. The badges and leaderboard were also positively accepted by most students. Awarding points for activities was also found to improve students' performance in class. Badges were found to increase students' active participation, and the leaderboard motivated students to participate actively in online classes. This study could provide guidance to universities or LMS providers wishing to implement gamification in an LMS.
\end{abstract}

Keywords: e-learning, learning management system, gamification, active learning, rating, points, badges, leaderboard

\section{Introduction}

Currently, most universities around the world have started using e-learning due to COVID-19. E-learning can facilitate interaction between students and their teachers, while minimizing time and space constraints (Utomo and Santoso, 2015). Abdullah, Bakar and Mahbob (2012) demonstrated the importance of class participation and active learning. Active learners seek information and engage with that information. They have an intention to learn and choose to participate in the learning process by reaching out for new information (Faria, Scurfield and Diaz del Castillo, 2016). Active learning is a student-centered, iterative, dialogical, and collaborative approach, the application of which must be conscious and well designed.

The COVID-19 pandemic has caused lecturers to encourage their students to make more active use of learning management systems (LMSs), as the lack of face-to-face interactions in e-learning can generate feelings of loneliness and boredom (Olsson, Mozelius and Collin, 2015). Herzberg et al. (2009) also found potential drawbacks of LMSs, such as reduced focus and student attention due to a lack of face-to-face communication between teachers and students. Interestingly, Azmi and Singh (2015) and Tuparov et al. (2018) found that a gamified LMS is more interactive and engaging to students than a standard LMS. Thus, gamification is one solution that can increase class participation (Hanus and Fox, 2015).

Gamification refers to the use of game design elements in a non-game context (Deterding et al., 2011). Research on aspects of gamification in non-gaming environments, such as education, has increased in recent years (Domínguez et al., 2013; Seaborn and Fels, 2015). Gamification aims to combine intrinsic motivation with extrinsic motivation to foster engagement and motivation for active participation (Mishra and Kotecha, 2017). The distinction between intrinsic motivation and extrinsic motivation comes from self-determination theory (SDT; Ryan and Deci, 2000). Intrinsic motivation can be understood as an action or activity that is carried out for the satisfaction that can be experienced simply by performing the activity, while extrinsic motivation is an action or activity that is carried out for reasons other than the satisfaction gained from the activity itself (Ryan and Deci, 2000). Mekler et al. (2017) explained that both types of motivation can improve a person's performance in carrying out activities. However, Ryan and Deci (2000) found that only intrinsic motivation can have a positive influence on creativity and learning outcomes (Mekler et al., 2017). This study draws on SDT to increase student motivation to engage in active learning through an LMS. 
Gamification has many elements, including points, badges, leaderboards, performance graphs, and avatars (Sailer et al., 2017). These elements can be implemented in an LMS. Wang (2020) adopted the design-based research (DBR) method to explore whether integrated technology-reinforced learning can help college teachers design more interactive classrooms and help undergraduate students engage in active learning. Wang (2020) used interactive response system such as Kahoot! for his study. Barata et al. (2013) described an experiment in which game-like elements were used to improve the delivery of a master's level college course. Barata et al. (2013) suggest that points and badges that can be earned by students may eliminate intrinsic motivation. Davis et al. (2018) analyzed active learning strategies to determine the most appropriate ones for digital learning environments and investigated the effectiveness of these strategies. For their study, they combined simulation and gamification into a single category rather than separating them into different categories.

To date, few studies have been conducted on the application of gamification in LMSs. Azmi and Singh (2015) conducted research on gamification for and LMS, focusing on a proprietary software package for Malaysian students. They found that gamification in LMS is interactive and engaging for users. In addition, Simionescu, Šuníková, and Kubincová (2017) and Tuparov et al. (2018) identified gamification features in open-source elearning environments but focused only on student assessment. However, the application of gamification in higher education is a rare topic of research in Indonesia. To fill this gap in the research, we evaluate the impact of gamification on active learning through an LMS called Student-Centered E-Learning Environment (SCeLE Fasilkom) used by the Faculty of Computer Science at Universitas Indonesia (UI). The gamification elements used in this study are badges, ratings and points, and a leaderboard. These gamification elements were chosen because badges and ratings/points are already available in SCeLE Fasilkom, making it easy to integrate, and the leaderboard was constructed according to previous studies.

\section{Literature Review}

\subsection{Active Learning}

According to Fayombo (2012), active learning is a crucial component of the learning process, as learners should be actively engaged during lectures. Active learning is an approach whereby students participate in the learning process by building knowledge and understanding. Active learning is a broad concept that generally encompasses student-centered learning methods and activities led by an instructor (Felder and Brent, 2009; Mitchell, Petter and Harris, 2017). It also includes any course-related activity, other than simply watching, listening, and taking notes, that all students in a class session are asked to perform (Felder and Brent, 2009). Hess (1999) described several characteristics of active learning, such as developing students' skills, involving students in high order thinking (analysis, synthesis, evaluation), engaging students in activities (reading, discussing, writing), and encouraging students to explore their own attitudes and values. Therefore, in general, active learning is not a learning concept but a teaching concept.

Previous research on active learning from the point of view of student learning outcomes has been mostly positive (Freeman et al., 2014), supporting active learning as a superior approach compared to traditional, more content-centered approaches, such as lectures. Active learning can include setting questions in an online forum, concept sketching and mapping, and case studies (Felder and Brent, 2009). Azmi and Singh (2015) implemented an avatar and a leaderboard in LMS to improve the student learning process, while Simionescu, Šuníková, and Kubincová (2017) and Tuparov et al. (2018) used badges to represent the students' progress in peer assessment.

\subsection{Student Engagement}

Nisiotis and Kleanthous (2019) defined student engagement as a commitment or effort made by students to participate in learning activities, while Nakamaru (2011) suggested that engagement relates to purposeful efforts by students to commit time and energy to educational activities. Student engagement can be categorized into three components: behavioral engagement, emotional engagement, and cognitive engagement (Sun and Rueda, 2011). Behavioral engagement can be interpreted as a form of student behavior in learning that is considered quite important (Fredricks, Blumenfeld and Paris, 2004) such as student behavior in class, student participation in school-related activities, and student interest in their academic work (Cooper, 2014; YazzieMintz and McCormick, 2012). Emotional engagement can be defined as emotional or psychological reactions to friends and class teachers and can include feelings of attraction, boredom, happiness, and sadness (Ding, Kim and Orey, 2017). Finally, cognitive engagement can be defined as student investment in the learning process, which involves students' inner psychological qualities or invisible traits that drive their efforts to learn, understand, and master the knowledge or skills promoted in their academic work (Cooper, 2014; Yazzie-Mintz 
and McCormick, 2012). Research by Khan et al. (2017) showed that active learning strategies often encourage student engagement and have a significant impact on student learning when applied effectively throughout a course.

\subsection{Gamification}

According to Deterding et al. (2011), gamification refers to a non-gaming environment that includes gaming elements with the aim of improving the user experience and increasing engagement to achieve certain goals. Groening and Binnewies (2019) found that the experience of engaging in activities that involve elements of gamification is similar to the experience of playing a game. Sailer et al. (2017) also found that gamification can improve motivation and performance. Gamification provides visible benefits in several non-game settings, such as the fields of health (Hammedi, Leclerq and Van Riel, 2017) and learning (Aparicio, 2019), and is one of the most effective learning strategies for promoting active learning (Davis et al., 2018).

\subsection{Self-Determination Theory (SDT)}

This study aims to evaluate the impact of the gamification elements points, badges, and a leaderboard on student learning. Various perspectives can be used to analyze the motivational strength of game elements, including emotional, cognitive, and behavioral perspectives, traits, interests, and self-determination (Sailer et al., 2017). The self-determination perspective was chosen for this study because it incorporates some of the contents of other perspectives (Sailer et al., 2017).

Self-determination theory is a theory of human personality and motivation that involves how an individual interacts with and depends on the social environment (Legault, 2017). It emphasizes the inherent motivational tendencies of people to learn and grow and how they can be supported (Ryan and Deci, 2020). According to Legault (2017), SDT assumes that everyone will try to develop and understand themselves by integrating new experiences; developing their needs, wants, and interests; and connecting with other people and the outside world.

\section{Methodology}

\subsection{Data Collection and Analysis}

This study uses a mixed-method approach and the DBR method. The DBR method is a method of conducting experiments in which various designs of gamification elements are incorporated at different stages of the research and integrated into an iterative cycle. This research follows a DBR process, which involves defining problems, designing experiments, facilitating, and evaluating methods, and determining findings at each stage and then providing suggestions for the next stage. For this study, the research method and data presentation were separated into three stages due to time limitations, which required that the experiment be carried out in a single semester of lectures.

In phase one, a points system was implemented in the form of a weekly review. The weekly review was a special forum for each SCeLE Fasilkom class to write down what they had learned each week. It was decided that the points system would be implemented first because SCeLE Fasilkom already has points feature, so the researcher did not need to design these elements and they were able to be implemented immediately. Points were also chosen because they can motivate students to actively participate in weekly reviews by establishing a clear relationship between participants' efforts and their performance. When implemented, the points system was received positively by the students as a way of increasing active learning. We then implemented the other gamification elements in the subsequent phases.

In phase two, badges were introduced. These were earned by students who participated in discussion forums and weekly reviews. The discussion forum was a special forum for each SCeLE Fasilkom class on which discussion materials, such as case studies, were posted every week. Badges were chosen for the second implementation because SCeLE Fasilkom already has a badge feature, so the researcher only needed to provide images for the badges and criteria for earning them. Badges were also chosen because they can be awarded as prizes to motivate students to participate more actively in weekly reviews and forum discussions. Badges also received a good response from students and improved active learning. Therefore, we implemented another gamification element in the next phase. The first and second phases are linked because the badges are awarded based on the points earned by participating in the weekly reviews. 
In the third stage, the leaderboard was implemented. The leaderboard was implemented last because SCeLE Fasilkom does not have a leaderboard feature, so the researcher had to create it from scratch. A leaderboard was chosen because it can inspire students to maintain their performance and continue to participate in weekly reviews and forum discussions. The leaderboard also received positive responses from students and increased active learning. Figure 1 presents the sequence of the DBR research, and the topics covered in each phase. This phase is linked to the first and second phase, as the leaderboard has three categories: one for points, one for badges, and one for a combination of the two.

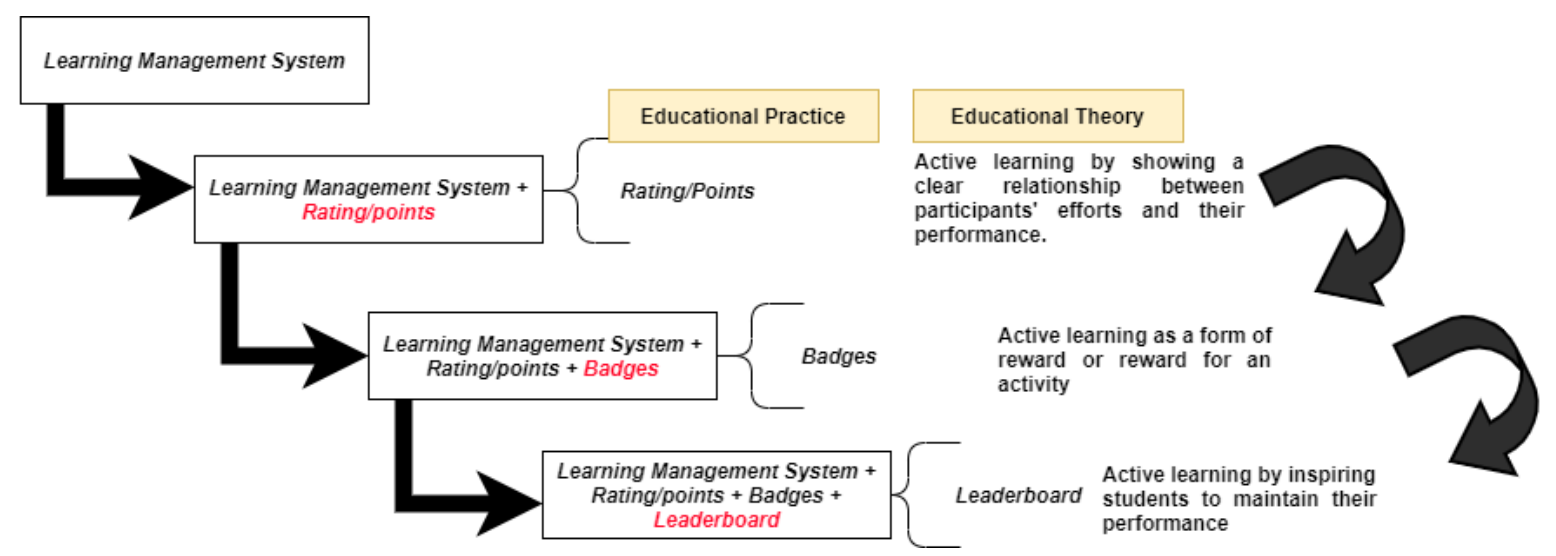

Figure 1: DBR Iteration Phases

This study involved students in three classes: Enterprise Systems (SIP-MTI), Business and Technical Communication (Kombistek), and Electronic Health (E-Health). Data on the implementation of the gamification element is taken from replies to weekly reviews and forum discussions, questionnaires, and student interviews. Data from questionnaires and replies were analyzed using the descriptive statistics mean and standard deviation. The average (mean) can provide an overall picture of the data set, while the standard deviation shows how scattered the data is by revealing how far each observed value is from the mean (Ilola, 2018). Data from interviews were analyzed using general inductive analysis. The sole purpose of implementing gamification in these three classes was to improve active student learning, which was explained by the lecturers at the beginning of each class.

Data collection was carried out in three stages, one stage for each of the DBR phases. The SIP-MTI class had 142 class members, the Kombistek class had 235 members, and E-Health had 80 class members. Of all the participants, 301 were completing bachelor's level courses (Kombistek and E-Health) and 156 were completing master's degree courses (SIP-MTI). An online questionnaire was distributed via a link, which was shared with the class members through various social media outlets, including Instagram, WhatsApp, and Line, and through class announcements on SCeLE Fasilkom. Each phase of data collection had a duration of two weeks. The first phase was carried out between 11 October 2020 and 24 October 2020, the second phase ran from 25 October to 7 November 2020, and the third phase started on 30 November 2020 and ended on 13 December 2020. The interviews to obtain qualitative data were conducted at the end of the third phase. Interviews were conducted with two UI students. The first phase had a total of 103 respondents, the second phase had 171 respondents, and the third phase had 149.

\subsection{Gamification Component Design Making}

When designing the gamification elements, we drew on the results of previous studies. When designing the badges, we chose the completion of the weekly review and forum discussion as the badge category. The researcher referred to various sources, including PlayerUnknown's Battlegrounds (PUBG) and League of Legends, when creating the badges. Both games have the same four levels, namely bronze, silver, gold, and platinum, which are also used for various other applications, such as membership of customer reward programs.

We did not design the points element, as the points design integrated into SCeLE Fasilkom could not be changed. Therefore, this existing design was used. Figure 2 shows the points gamification element in SCeLE Fasilkom. 


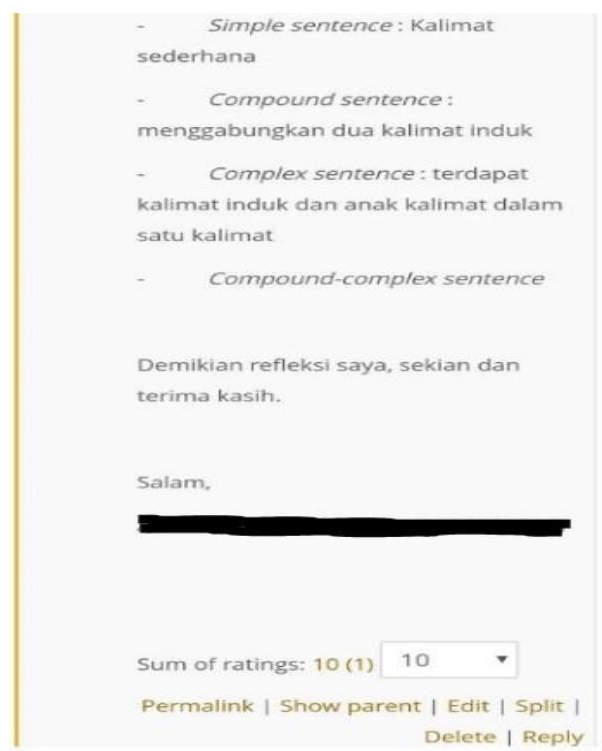

Figure 2: Weekly rating points design

Finally, when designing the third gamification element, namely the leaderboard, the researchers created a leaderboard with references using various sources, such as Kahoot!. Because SCeLE Fasilkom does not have a built-in leaderboard feature, we created a separate online leaderboard that could be accessed through SCeLE Fasilkom. Participants could see the leaderboard for their class. The leaderboard consisted of three categories: the accumulated score for the weekly review, the number of badges obtained, and a combination of these two categories. We adopted the podium concept used in Kahoot!, which displays ranks one, two, and three differently from other ratings. Ranks four to ten are shown next to ranks one, two, and three. Figure 3 shows the improved online leaderboard interface after testing. The design of the leaderboard page adheres to the eight golden rules set out by Shneiderman and Plaisant (2010), which include universal usability, error prevention, and reduced short-term memory load.

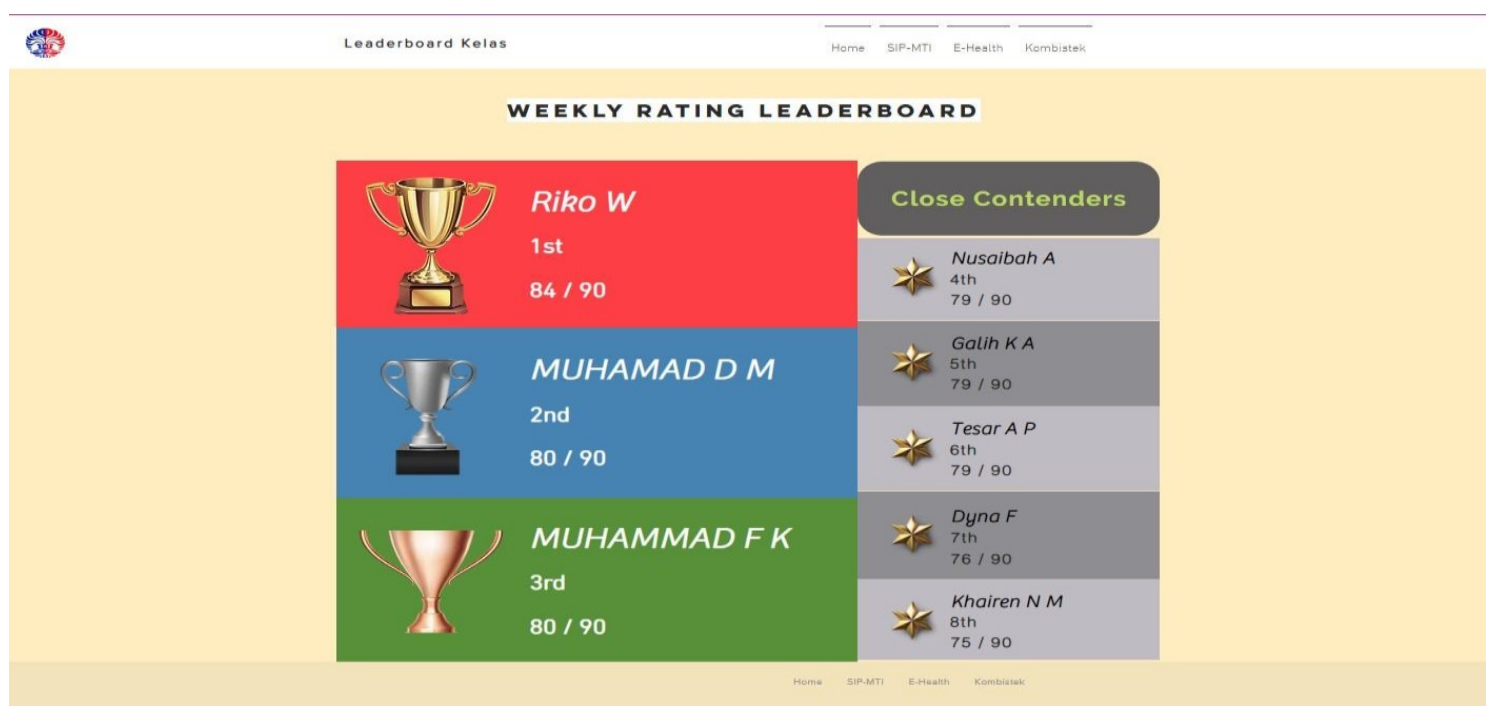

Figure 3: Leaderboard page for the SIP-MTI weekly reviews

The badges used in this study were participatory badges, which means badges were given for participation, regardless of the quality of the user's performance (Abromovich et al., 2013). Each class that participated in this research provided four participatory badges that were awarded to students who participated in the activities specified for earning the badges. Figure 4 shows how badges were implemented in the LMS. 


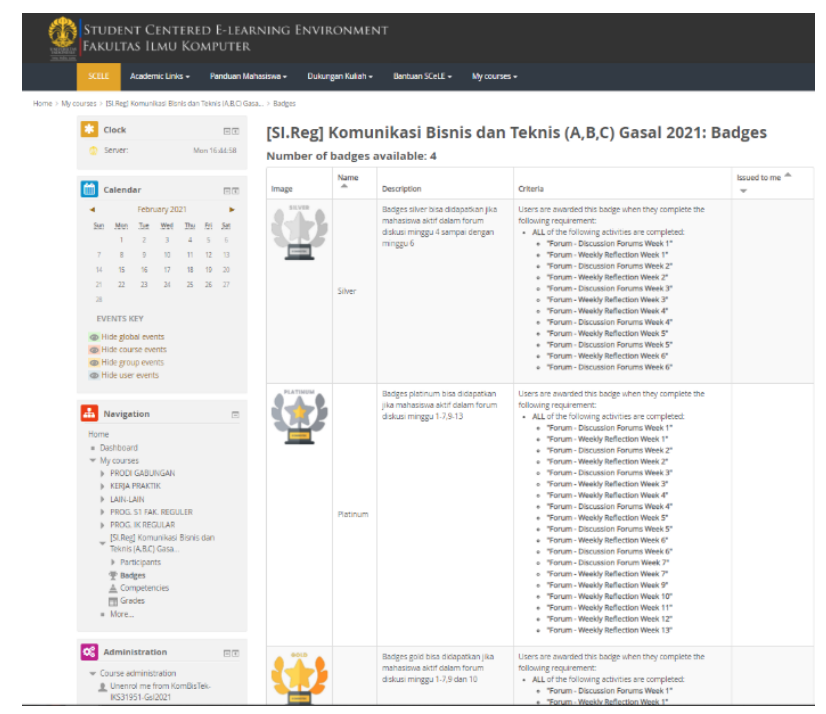

Figure 4: Kombistek badges page

\subsection{Research Instrument}

Study participants were required to complete three questionnaires. Questionnaires were distributed for completion by participants in each phase. Each questionnaire consisted of two parts: the first part asked about the respondent's personal feelings about the relevant topics, and the second part consisted of quantitative questions to evaluate the feedback on each gamification component. The questionnaires were prepared based on a review of the literature, and each used a Likert scale. The first phase questionnaire was adapted from the DBR phase one questionnaire used by Wang (2020). The second phase questionnaire was adapted from the questionnaire used by Kyewski and Kramer (2018), and the third phase questionnaire was adapted from the questionnaire used by Fotaris et al. (2016).

\section{Results}

\subsection{Analysis Results}

\subsubsection{Phase one data analysis: Points implementation}

The data for phase one came from weekly reviews and forum discussions from week four to week six. The first phase of data analysis showed that the students gave positive feedback on the rated weekly review activity (Table 1). The respondents indicated that this activity increased their involvement in the class (Q2), which is supported by their responses to the weekly review. Respondents' interaction with lecturers and lecturing assistants (Q1) also increased because they replied to discussion forums and weekly reviews initiated by lecturers or teaching assistants, and some of the respondents' replies received responses from the lecturer or teaching assistant. Respondents also felt that rating weekly reviews increased active participation in the reviews (Q3), which is supported by the number of responses on the discussion forum. The use of points was also found to increase respondents' willingness to participate in the reviews (Q4), which is evident from the number of forum replies. Likewise, the points system improved students' concentration during online classes because they wanted to earn high points when participating in weekly reviews (Q5).

Table 1: Results of the first phase of data analysis

\begin{tabular}{|l|l|r|r|}
\hline Code & \multicolumn{1}{|c|}{ Question } & Average & $\begin{array}{c}\text { Standard } \\
\text { Deviation }\end{array}$ \\
\hline Q1 & $\begin{array}{l}\text { I feel that I have good interaction with lecturers and teaching assistants in the } \\
\text { rated weekly review activities. }\end{array}$ & 3.70 & 0.86 \\
\hline Q2 & I feel more involved in the class by participating in the rated weekly review. & 4.10 & 0.74 \\
\hline Q3 & I feel that using ratings increases active participation in the weekly review. & 3.99 & 0.91 \\
\hline Q4 & Using ratings increases my willingness to participate in the weekly review. & 3.95 & 0.94 \\
\hline Q5 & $\begin{array}{l}\text { To perform well in the rated weekly review, I concentrate more during online } \\
\text { classes. }\end{array}$ & 3.83 & 0.96 \\
\hline
\end{tabular}


Based on the results shown in Table 1, it was concluded that integrating points into weekly reviews can increase active learning. Therefore, based on the findings of phase one, it was decided to add a new gamification element, namely badges to the LMS to further promote active learning. The criteria for earning badges include participating in the weekly review, which is rated. This means that students are more motivated to complete the weekly review.

\subsubsection{Data analysis phase two: Points and badges implementation}

The data used for the second phase of the analysis came from weekly reviews and forum discussions in the seventh to the tenth week. The second phase of analysis showed that students gave positive feedback regarding the implementation of badges (Table 2). Respondents indicated that the badges increased their motivation (Q3), which is evident from the level of activity in weekly reviews and discussion forums, which is a criterion for earning badges. The respondents also considered the badges interesting (Q5). They felt that getting badges was important (Q1). Again, this is supported by the activity level in the weekly reviews and discussion forums. The students liked receiving badges (Q2) and were happy that their fellow students could see their commitment to the course when they received a badge (Q4). The use of badges was also found to improve respondents' willingness to try an activity (Q7) and to engage in activities that would earn them a badge (Q8). This explains their initial willingness to participate in the discussion forums and weekly reviews. Respondents also seemed to want to try to collect all possible badges (Q6). However, they did not seem particularly willing to compare the badges they had obtained with those obtained by their fellow students (Q9).

Table 2: Results of phase two of the analysis

\begin{tabular}{|c|c|c|c|}
\hline Code & Question & Average & $\begin{array}{l}\text { Standard } \\
\text { deviation }\end{array}$ \\
\hline Q1 & I feel it is important to get badges. & 3.88 & 0.88 \\
\hline Q2 & I love getting badges. & 4.08 & 0.86 \\
\hline Q3 & I feel motivated because of badges. & 3.93 & 0.92 \\
\hline Q4 & $\begin{array}{l}\text { I am happy that other fellow students can see my commitment to the } \\
\text { course with these badges. }\end{array}$ & 3.67 & 0.92 \\
\hline Q5 & I find badges interesting. & 4.00 & 0.86 \\
\hline Q6 & I am trying to get to all possible badges. & 3.91 & 0.98 \\
\hline Q7 & Badges can get me to try an activity. & 3.95 & 0.90 \\
\hline Q8 & I will engage in activities if I can earn badges for doing so. & 3.43 & 0.98 \\
\hline Q9 & $\begin{array}{l}\text { I like to compare the badges that I have got with those of my fellow } \\
\text { students. }\end{array}$ & 2.88 & 1.17 \\
\hline
\end{tabular}

After the second stage of analysis, it was concluded that the addition of badges was received positively by most students. However, while the data obtained from the questionnaire showed that badges were generally received positively, the second phase of data collection (Appendix A, weeks 7 to 10) included the midterm exams, which may have affected the data on active learning from the weekly reviews and forum discussions. The results of interviews support this assumption.

"Yes, because sometimes I forgot that I had to fill out the forum after midterm; the problem was that

when it was midterm, I didn't need to fill in the forum, so I got out of the habit." (Respondent 2, Male)

Based on the findings of the second stage, it was decided to add a new gamification element, the leaderboard, to the LMS to further promote active learning. The leaderboard had ranking categories based on the gamification elements implemented in phase two and phase one, namely badges and ratings, aimed at motivating students to participate in weekly reviews and forum discussions.

\subsubsection{Phase three data analysis: Points, badges, and leaderboard implementation}

The data for phase three of the analysis came from weekly reviews and forum discussions in weeks 11 to 13 . The third phase of data analysis showed that students gave positive feedback regarding the implementation of the leaderboard (Table 3). They reported that the leaderboard activity increased their motivation (Q3), which is evident from the level of activity in the weekly reviews and discussion forums, participation in which is one of the criteria for earning badges and for determining a participant's ranking on the leaderboard. The respondents 
also felt motivated to learn so that they would rank high on the leaderboard (Q5). They also thought that the leaderboard made the learning environment interesting (Q2) and fun (Q1). They were happy that their fellow students could see their commitment to the course by their ranking on the leaderboard (Q4). Respondents also felt that the use of the leaderboard improved their performance in class (Q7) and that their self-confidence increased when they ranked well on the leaderboard (Q8). Being ranked on the leaderboard gave respondents a sense that they were valued in class (Q9). They also expected that the leaderboard would be used for other classes (Q6).

Table 3: Results of phase three of the data analysis

\begin{tabular}{|l|l|r|r|}
\hline Code & \multicolumn{1}{|c|}{ Question } & Average & \multicolumn{1}{|c|}{$\begin{array}{c}\text { Standard } \\
\text { Deviation }\end{array}$} \\
\hline Q1 & I find the leaderboard makes for a great learning environment. & 3.64 & 1.01 \\
\hline Q2 & I find the leaderboard makes the learning environment interesting. & 3.76 & 1.01 \\
\hline Q3 & I feel motivated because of the leaderboard. & 3.72 & 0.99 \\
\hline Q4 & $\begin{array}{l}\text { I am glad that my fellow students can see my commitment to the course } \\
\text { with the leaderboard. }\end{array}$ & 3.52 & 1.01 \\
\hline Q5 & $\begin{array}{l}\text { I feel motivated to study in class so that my ranking on the leaderboard is } \\
\text { high. }\end{array}$ & 3.70 & 1.00 \\
\hline Q6 & I hope the leaderboard is implemented in other classes. & 3.74 & 1.03 \\
\hline Q7 & I feel that the leaderboard has improved my performance in class. & 3.50 & 1.04 \\
\hline Q8 & I feel more confident when I get good rankings on the leaderboard. & 3.92 & 0.89 \\
\hline Q9 & I feel appreciated when I get ranked on the leaderboard. & 3.81 & 0.87 \\
\hline
\end{tabular}

After the third phase, it was concluded that the addition of the leaderboard was positively accepted by most of the students. The data obtained from the questionnaire showed that badges were generally received positively. However, the leaderboard had to be accessed through a separate link in SCeLE Fasilkom, which may have made participants less aware of its existence and, thus, affected active learning in the weekly reviews and forum discussions (Appendix A, weeks 11 to 13). The interview results support this suggestion.

"Yes, if you forget the leaderboard link, you have to search again." (Respondent 2, Male)

The results of the questionnaire (Table 4) showed that students gave generally positive feedback on the implementation of gamification and indicated that it increased their motivation to continue attending the classes (Q3), their involvement in class (Q2), and their enjoyment of the class (Q1). Respondents also felt that gamification improved their performance in class (Q4) and their productivity (Q5). They reported that their interactions with their classmates had increased (Q6). They also hoped that gamification would be implemented in other classes (Q7).

Table 4: Gamification analysis results

\begin{tabular}{|l|l|r|r|}
\hline Code & Question & Average & $\begin{array}{c}\text { Standard } \\
\text { Deviation }\end{array}$ \\
\hline Q1 & $\begin{array}{l}\text { I feel that the leaderboard, badges, and weekly reviews with ratings increase } \\
\text { my involvement in the classes I participate in. }\end{array}$ & 3.94 & 0.81 \\
\hline Q2 & $\begin{array}{l}\text { I feel like the leaderboard, badges, and weekly reviews with ratings increase } \\
\text { my enjoyment of the class. }\end{array}$ & 3.64 & 0.95 \\
\hline Q3 & $\begin{array}{l}\text { I feel that the leaderboard, badges, and weekly reviews with ratings increase } \\
\text { my motivation to continue attending the classes. }\end{array}$ & 3.72 & 0.95 \\
\hline Q4 & $\begin{array}{l}\text { I feel that the leaderboard, badges, and weekly reviews with ratings improve } \\
\text { my performance in class. }\end{array}$ & 3.63 & 0.96 \\
\hline Q5 & $\begin{array}{l}\text { I feel that the leaderboard, badges, and rated weekly reviews increase my } \\
\text { productivity in class. }\end{array}$ & 3.73 & 0.95 \\
\hline Q6 & $\begin{array}{l}\text { I feel that the rated leaderboard, badges, and weekly reviews improve my } \\
\text { interactions with my colleagues in class. }\end{array}$ & 3.51 & 0.97 \\
\hline
\end{tabular}


Satrio Raffani Raharjo, Putu Wuri Handayani and Panca Oktavia Hadi Putra

\begin{tabular}{|l|l|r|r|}
\hline Code & Question & Average & $\begin{array}{l}\text { Standard } \\
\text { Deviation }\end{array}$ \\
\hline Q7 & $\begin{array}{l}\text { I hope the leaderboard, badges, and rated weekly reviews will be } \\
\text { implemented in other classes. }\end{array}$ & 3.72 & 0.94 \\
\hline
\end{tabular}

\subsubsection{General inductive analysis}

Apart from the quantitative data described above, qualitative data was also collected through interviews conducted at the end of the third phase (Table 5). The interviews were conducted to obtain deeper qualitative data to strengthen the results obtained from the questionnaires. This qualitative data was analyzed using general inductive analysis. The results of the interviews indicated that gamification had benefits for the respondents, such as providing an overall picture of student activity in class, motivating them to take part in lecture activities, and enabling them to see their performance through points earned (Table 5). Respondents also felt safer because they were given an indication of the work they were doing. This is also consistent with the results of Von Ahn and Dabbish (2008), who found that points clarified the relationship between students' efforts and their performance. Respondents also felt happy when they obtained points, received badges, or appeared on the leaderboard. This is in accordance with Sitra et al.'s (2017) finding that gamification that uses badges as rewards provide strong encouragement for students to more actively participate in learning activities. Respondents also felt that class activity had increased due to gamification. This is also consistent with the finding of Mekler et al. (2013) that points can motivate an individual to engage in an activity.

Table 5: Summary of Interview Results

\begin{tabular}{|l|l|}
\hline \multicolumn{1}{|c|}{ Questions } & \multicolumn{1}{|c|}{ Answers } \\
\hline $\begin{array}{l}\text { The benefits felt from the } \\
\text { gamification element }\end{array}$ & $\begin{array}{l}\text { "It can provide a picture of the overall activity in class" (Respondent 1), } \\
\text { "I was motivated to participate in all lecture activities." (Respondent 1) } \\
\text { "Looking at my performance through ratings" (Respondent 1) }\end{array}$ \\
\hline $\begin{array}{l}\text { Feelings about the } \\
\text { gamification element }\end{array}$ & $\begin{array}{l}\text { "So, I feel more secure because the scores are more transparent" (Respondent 1) } \\
\text { "I was motivated to be better than other participants " (Respondent 1) }\end{array}$ \\
\hline $\begin{array}{l}\text { Feelings after receiving a } \\
\text { good rating or a badge or } \\
\text { entering the leaderboard }\end{array}$ & $\begin{array}{l}\text { "Happy" (Respondent 2) } \\
\text { "I can be arrogant toward friends " (Respondent 1) }\end{array}$ \\
\hline $\begin{array}{l}\text { Do you like it when other } \\
\text { people see your } \\
\text { activities/commitments in } \\
\text { class? }\end{array}$ & $\begin{array}{l}\text { "Happy; badges can be a personal collection" (Respondent 1) } \\
\text { "Happy because, for example, someone with a better performance could be a source }\end{array}$ \\
\hline $\begin{array}{l}\text { Do you feel activity in class } \\
\text { increased? }\end{array}$ & "Yes. I respond to every forum, so I can collect badges. " (Respondent 1) \\
\hline
\end{tabular}

\subsection{Discussion of Research Results}

This study shows that lecturers can use gamification elements on an LMS to improve active learning in their classes. The results show that ratings/points were motivated more than $50 \%$ of students to complete weekly reviews almost every week (Appendix A). Appendix A also shows that new master's students are not as active as new or old students at undergraduate level because new master's students tend to be working as well, so they do not have much time to explore the LMS. A decline was noted in the last week of lectures, which could be due to students being busy with many lectures and preparations for the end of semester exams. The results of the interviews show that ratings motivated the students, which is in line with the findings of Mekler et al. (2013), Huang and Hew (2015), and Dahlstrom (2017) and with the responses to one of the questions in the phase one questionnaire, which showed that $59.22 \%$ participated more in class activities with points. Points were also found to improve respondents' performance in class, which is supported by several other studies, such as those of Mekler et al. (2013) and Von Ahn and Dabbish (2008), which show that points clarify the relationship between an individual's efforts and their performance. 
Badges were also found to increase active participation, which can be seen from the number of replies to the forum discussions and weekly reviews. This is in line with Sitra et al.'s (2017) finding that gamification in the form of a badge as a reward provides strong encouragement for students to participate more actively in learning activities. This is also in line with Hamari's (2017) finding that badges can motivate an individual to engage in an activity. The results of the interviews also show that badges can encourage students to participate in active learning by taking part in weekly reviews and discussion forums. Students were also found to be less likely to compare their badges with those of other students, which aligns with the findings of Kyewski and Kramer (2018). For students who do not like competition, the badges and leaderboard results could be displayed so that students can only see their own level or ranking. In addition, the leaderboard could also display an avatar that has been determined by the student instead of their name so that the results could be kept anonymous.

Finally, the results of the analysis found that the leaderboard had an impact on active learning in the LMS. The leaderboard motivated students to participate actively in class and to engage in forum discussions and weekly reviews, which is in accordance with the findings of Mekler et al. (2013) and Hamari, Koivisto, and Sarsa (2014). The leaderboard also improved students' performance in the classroom by enabling them to set clear goals to strive for (Mekler et al., 2013; Farzan et al., 2008; Hamari, 2013). The results of the interviews show that the leaderboard also motivates students to keep trying to perform well. This is supported by the results of Mekler et al. (2013), who found that leaderboards can inspire participants to maintain their performance for longer.

\section{Implications}

This study contributes to research in the field of gamification and e-learning, especially in relation to the design of gamification elements and analysis of the effects of gamification on active learning in LMS applications. This study enriches the research in this field and contributes to the application of gamification elements in LMSs using the DBR methodology. The results of the questionnaires and interviews show that gamification could increase active learning through LMSs. This is in line with the findings of Davis et al. (2018), which show that gamification is one of the most effective active learning strategies for the digital learning environment, in this case, an LMS.

The study also found that points have the most visible impact on active learning, followed by badges, and finally the leaderboard. Factors such as the ability and motivation of students to participate in these learning activities need to be studied when designing gamification components for implementation in an LMS. Accessibility should also be a consideration for LMS managers because students should not feel burdened by gamification. Therefore, LMS managers should focus on the various components of gamification that will be applied in the LMS and their positive and negative aspects.

\section{Conclusion}

This study proves that gamification applied in an LMS had a positive influence on active learning in the sample considered for this study. This influence can be seen in the replies to the forum discussions and weekly reviews. Points were found to be motivating, as they provided a clear link between students' efforts and their performance (rating/point). Badges were also found to be motivating, as the participants wanted to obtain them and increased their active participation or learning to do so. The leaderboard was also motivating, as it made students try to maintain their performance. Future research could examine other gamification components, such as avatars, progress bars, and levels, to test whether they improve active student learning. One limitation of this experiment was that midterm occurred during one of the phases. Further research could be carried out without any pause in the implementation that might cause a disturbance in the habitual activities of respondents and thus affect the results of the study.

\section{Acknowledgements}

We want to convey our gratitude to the Universitas Indonesia for the Grant Hibah Pendampingan Publikasi Internasional Q2 (PPI Q2) Number NKB-551/UN2.RST/HKP.05.00/2021.

\section{References}

Abdullah, M. Y., Bakar, N. R. A. and Mahbob, M. H., 2012. Student's participation in classroom: what motivates them to speak up? Procedia - Social and Behavioral Sciences, 51, pp. 516-522. doi: 10.1016/ j.sbspro.2012.08.199.

Abramovich, S., Schunn, C., and Higashi, R. M. 2013. Are badges useful in education? It depends upon the type of badge and expertise of learner. Educational Technology Research and Development, 61(2), pp. 217-232. 
Aparicio, M., Oliveira, T., Bacao, F., Painho, M. (2019). Gamification: A key determinant of massive open online course (mooc) success. Information \& Management, 56(1), pp. 39-54.

Azmi, M. A. and Singh, D., 2015. Schoolcube: gamification for learning management system through Microsoft SharePoint. International Journal of Computer Games Technology, 2015(1), pp. 1-5.

Barata, G., Gama, S., Jorge, J. and Gonçalves, D., 2013. Engaging engineering students with gamification. In: 5 th International Conference on Games and Virtual Worlds for Serious Applications (VS-GAMES). Poole, United Kingdom, 11-13 September 2013. doi: 10.1109/VS-GAMES.2013.6624228.

Cooper, K. S., 2014. Eliciting engagement in the high school classroom: a mixed methods examination of teaching practices. American Educational Research Journal, 51(2), pp. 363-402.

Davis, D., Chen, G., Hauff, C. and Houben, G.J., 2018. Activating learning at scale: a review of innovations in online learning strategies. Computers \& Education, 125, pp. 327-344.

Deterding, S., Dixon, D., Khaled, R. and Nacke, L., 2011. From game design elements to gamefulness: defining "gamification". In: Proceedings of the 15th International Academic Mindtrek conference: envisioning future media environments. New York, USA, 28 September 2011. doi: 10.1145/2181037.2181040.

Ding, L., Kim, C. and Orey, M., 2017. Studies of student engagement in gamified online discussions. Computers \& Education, 115, pp. 126-142. doi: 10.1016/j.compedu.2017.06.016.

Domínguez, A., de Navarrete, J. S., de Marcos, L., Fernandez-Sanz, L., Pagés, C. and Martínez-Herraiz, J.-J., 2013. Gamifying learning experiences: practical implications' and outcomes. Computers \& Education, 63, pp. 380-392. doi: 10.1016/j.compedu.2012.12.020.

Faria, J., Scurfield, I. and Diaz del Castillo, P., 2016. How to become an active learner. Available at: https://www.mcgill.ca/osd/files/osd/active_vs_passive_learning.pdf. [Accessed 15 December 2020]

Farzan, R., DiMicco, J. M., Millen, D. R., Dugan, C., Geyer, W. and Brownholtz, E. A., 2008. Results from deploying a participation incentive mechanism within the enterprise. In: Proceedings of the SIGCHI conference on human factors in computing systems. Florence, Italy, 6 April 2008. doi: 10.1145/1357054.1357145.

Fayombo, G. A. 2012. Active learning strategies and student learning outcomes among some university students in Barbados. Journal of Educational and Social Research, Special Issue, 2(9), pp. 79-90.

Felder, R. and Brent, R., 2009. Active learning: an introduction. ASQ Higher Education Brief, 2(4), pp. 1-7.

Fotaris, P., Mastoras, T., Leinfellner, R. and Rosunally, Y., 2016. Climbing up the leaderboard: an empirical study of applying gamification techniques to a computer programming class. Electronic Journal of e-Learning, 14, pp. 95-110.

Fredricks, J. A., Blumenfeld, P. C. and Paris, A. H., 2004. School engagement: potential of the concept, state of the evidence. Review of Educational Research, 74(1), pp. 59-109.

Freeman, S., Eddy, S. L., McDonough, M., Smith, M. K., Okoroafor, N., Jordt, H. and Wenderoth, M. P., 2014. Active learning increases student performance in science, engineering, and mathematics. Proceedings of the National Academy of Sciences, 111(23), pp. 8410-8415.

Groening, C. and Binnewies, C., 2019. "Achievement unlocked!" - the impact of digital achievements as a gamification element on motivation and performance. Computers in Human Behavior, 97, pp. 151-166. doi: 10.1016/ j.chb.2019.02.026

Hamari, J., 2013. Transforming homo economicus into homo ludens: a field experiment on gamification in a utilitarian peer-to-peer trading service. Electronic Commerce Research and Applications, 12(4), pp. 236-245.

Hamari, J., 2017. Do badges increase user activity? A field experiment on the effects of gamification. Computers in Human Behavior, 71, pp. 469-478.

Hamari, J., Koivisto, J. and Sarsa, H., 2014. Does gamification work? - a literature review of empirical studies on gamification. In: 47th Hawaii international conference on system sciences. Waikoloa, USA, 6-9 January 2014. doi: 10.1109/HICSS.2014.377.

Hammedi, W., Leclerq, T. and Van Riel, A.C.R., 2017, The use of gamification mechanics to increase employee and user engagement in participative healthcare services: a study of two cases. Journal of Service Management, 28(4), pp. 640-661.

Hanus, M. D. and Fox, J., 2015. Assessing the effects of gamification in the classroom: a longitudinal study on intrinsic motivation, social comparison, satisfaction, effort, and academic performance. Computers \& Education, 80, pp. 152161. doi: 10.1016/j.compedu.2014.08.019

Herzberg, D., Marsden, N., Kubler, P., Leonhardt, C., Thomanek, S., Jung, H. and Becker, A., 2009. Specifying computerbased counseling systems in health care: a new approach to user-interface and interaction design. Journal of Biomedical Informatics, 42(2), pp. 347-355.

Hess, G. (1999). Principle 3: good practice encourages active learning. Journal of Legal Education, 49(3), pp. $401-417$.

Huang, B. and Hew, K. F., 2015. Do points, badges and leaderboard increase learning and activity: a quasi-experiment on the effects of gamification. In: Proceedings of the 23rd international conference on computers in education. China, December 2015.

Khan, A., Egbue, O., Palkie, B. and Madden, J., 2017. Active learning: engaging students to maximize learning in an online course. Electronic Journal of E-Learning, 15(2), pp. 107-115.

Kyewski, E. and Kramer, N. C., 2018. To gamify or not to gamify? An experimental field study of the influence of badges on motivation, activity, and performance in an online learning course. Computers \& Education, 118, pp. 25-37.

Legault L., 2017. Self-Determination Theory. In: V. Zeigler-Hill and T. Shackelford,(eds.) Encyclopedia of Personality and Individual Differences. Cham: Springer. https://doi.org/10.1007/978-3-319-28099-8_1162-1 
Mekler, E. D., Bruhlmann, F., Opwis, K. and Tuch, A. N., 2013. Do points, levels and leaderboards harm intrinsic motivation? An empirical analysis of common gamification elements. In: Proceedings of the first international conference on gameful design, research, and applications. Toronto, Canada, 2 October 2013. doi: 10.1145/2583008.2583017.

Mekler, E. D., Bruhlmann, F., Tuch, A. N. and Opwis, K., 2017. Towards understanding the effects of individual gamification elements on intrinsic motivation and performance. Computers in Human Behavior, 71, pp. 525-534.

Mishra, R. and Kotecha, K., 2017. Students engagement through gamification in education gamifying formative assessment. Journal of Engineering Education Transformations, pp. 88-94. doi:10.16920/jeet/2017/v0i0/ 111751.

Mitchell, A., Petter, S. and Harris, A., 2017. Learning by doing: twenty successful active learning exercises for information systems courses. Journal of Information Technology Education: Innovations in Practice, 16, pp. 21-46. doi: $10.28945 / 3643$.

Nakamaru, S. 2011. Investment and return: wiki engagement in a "remedial" ESL writing course. Journal of Research on Technology in Education, 44(4), pp. 273-291.

Nisiotis, L. and Kleanthous, S., 2019, July. The relationship between students' engagement and the development of transactive memory systems in MUVE: an experience report. In: Proceedings of the 2019 ACM conference on innovation and technology in computer science education. Aberdeen, United Kingdom, 2 July 2019. doi: 10.1145/3304221.3319743.

Olsson, M., Mozelius, P. and Collin, J., 2015. Visualisation and gamification of e-learning and programming education. Electronic Journal of e-Learning, 13(6), pp. 441-454.

Ryan, R. M. and Deci, E. L., 2000. Self-determination theory and the facilitation of intrinsic motivation, social development, and well-being. American Psychologist, 55(1), p. 68.

Ryan, R. M. and Deci, E. L., 2020. Intrinsic and extrinsic motivation from a self-determination theory perspective: definitions, theory, practices, and future directions. Contemporary Educational Psychology, 101860.

Sailer, M., Hense, J. U., Mayr, S. K. and Mandl, H., 2017. How gamification motivates: an experimental study of the effects of specific game design elements on psychological need satisfaction. Computers in Human Behavior, 69, pp. 371-380.

Seaborn, K. and Fels, D. I., 2015. Gamification in theory and action: a survey. International Journal of Human-Computer Studies, 74, pp. 14-31.

Shneiderman, B. and Plaisant, C., 2010. Designing the user interface: strategies for effective human-computer interaction. United Kingdom: Addison-Wesley.

Simionescu, S., Šuníková, D. and Kubincová, Z., 2017. Gamification of peer assessment in learning management system, In: 18th International conference on Carpathian control conference (ICCC). Sinaia, Romania, 28-31 May 2017. doi: 10.1109/CarpathianCC.2017.7970465.

Sitra, O., Katsigiannakis, V., Karagiannidis, C. and Mavropoulou, S., 2017. The effect of badges on the engagement of students with special educational needs: a case study. Education and Information Technologies, 22(6), pp. 30373046.

Sun, J. C.-Y. and Rueda, R., 2011. Situational interest, computer self-efficacy and self-regulation: their impact on student engagement in distance education. British Journal of Educational Technology, 43, 191-204. doi: 10.1111/j.14678535.2010.01157.x

Tuparov, G., Keremedchiev, D., Tuparova, D. and Stoyanova, M., 2018. Gamification and educational computer games in open source learning management systems as a part of assessment, In: 17th International conference on information technology based higher education and training (ITHET). Olhao, Portugal, 26-28 April 2018. doi: 10.1109/ITHET.2018.8424768.

Utomo, A. Y. and Santoso, H. B., 2015. Development of gamification-enriched pedagogical agent for e-learning system based on community of inquiry. In: Proceedings of the international $\mathrm{HCl}$ and UX conference in Indonesia (p. 1-9). Bandung, Indonesia, April 2015. doi: 10.1145/2742032.2742033.

Von Ahn, L. and Dabbish, L, 2008. Designing games with a purpose. Communications of the ACM, 51(8), pp. 58-67.

Wang, Y. H., 2020. Design-based research on integrating learning technology tools into higher education classes to achieve active learning. Computers \& Education, 156, 103935. doi: 10.1016/j.compedu.2020.103935.

\section{Appendix A. Weekly Review Students Participation}

\begin{tabular}{|c|c|c|c|c|c|c|c|}
\hline \multirow[b]{2}{*}{ Week } & \multirow[t]{2}{*}{ Gamification } & \multicolumn{2}{|c|}{ Kombistek } & \multicolumn{2}{|c|}{ SIP-MTI } & \multicolumn{2}{|c|}{ E-Health } \\
\hline & & $\begin{array}{l}\text { Number of } \\
\text { Students }\end{array}$ & $\begin{array}{c}\text { Percentage } \\
(\%)\end{array}$ & $\begin{array}{l}\text { Number of } \\
\text { Students }\end{array}$ & $\begin{array}{c}\text { Percentage } \\
(\%)\end{array}$ & $\begin{array}{l}\text { Number of } \\
\text { Students }\end{array}$ & $\begin{array}{c}\text { Percentage } \\
(\%)\end{array}$ \\
\hline 1 & \multirow[t]{6}{*}{ Points } & 206 & 87.66 & 132 & 92.96 & 80 & 100.00 \\
\hline 2 & & 196 & 83.40 & 121 & 85.21 & 74 & 92.50 \\
\hline 3 & & 163 & 69.36 & 123 & 86.62 & 74 & 92.50 \\
\hline 4 & & 166 & 70.64 & 97 & 68.31 & 77 & 96.25 \\
\hline 5 & & 177 & 75.32 & 128 & 90.14 & 78 & 97.50 \\
\hline 6 & & 159 & 67.66 & 96 & 67.61 & 63 & 78.75 \\
\hline 7 & \multirow{4}{*}{$\begin{array}{l}\text { Points and } \\
\text { badges }\end{array}$} & 173 & 73.62 & 96 & 67.61 & 64 & 80.00 \\
\hline 8 & & 175 & 74.47 & 92 & 64.79 & 71 & 88.75 \\
\hline 9 & & 175 & 74.47 & 93 & 65.49 & 71 & 88.75 \\
\hline 10 & & 169 & 71.91 & 92 & 64.79 & 67 & 83.75 \\
\hline
\end{tabular}


Satrio Raffani Raharjo, Putu Wuri Handayani and Panca Oktavia Hadi Putra

\begin{tabular}{|l|l|r|r|r|r|r|r|}
\hline \multirow{2}{*}{ Week } & \multirow{2}{*}{ Gamification } & \multicolumn{2}{|c|}{ Kombistek } & \multicolumn{2}{|c|}{ SIP-MTI } & \multicolumn{2}{c|}{ E-Health } \\
\cline { 3 - 8 } & & $\begin{array}{c}\text { Number of } \\
\text { Students }\end{array}$ & $\begin{array}{c}\text { Percentage } \\
\text { (\%) }\end{array}$ & $\begin{array}{c}\text { Number of } \\
\text { Students }\end{array}$ & $\begin{array}{c}\text { Percentage } \\
\text { (\%) }\end{array}$ & $\begin{array}{c}\text { Number of } \\
\text { Students }\end{array}$ & $\begin{array}{c}\text { Percentage } \\
\text { (\%) }\end{array}$ \\
\hline 11 & \multirow{2}{*}{$\begin{array}{l}\text { Points, badges, } \\
\text { and leaderboard }\end{array}$} & 173 & 73.62 & 78 & 54.93 & 57 & 71.25 \\
\cline { 3 - 8 } & & 168 & 71.49 & 70 & 49.30 & 52 & 65.00 \\
\hline 12 & & 154 & 65.53 & 60 & 42.25 & 44 & 55.00 \\
\hline
\end{tabular}

